\title{
The Effect of Trust in the Intention to Use m-banking
}

\author{
Fernanda Leão Ramos ${ }^{\dagger}$ \\ Pontifícia Universidade Católica do Rio de Janeiro PUC-Rio \\ Jorge Brantes Ferreira $\Omega$ \\ Pontifícia Universidade Católica do Rio de Janeiro PUC-Rio \\ Angilberto Sabino de Freitas $¥$ \\ Unigranrio - Universidade Grande Rio \\ Juliana Werneck Rodrigues * \\ Pontifícia Universidade Católica do Rio de Janeiro PUC-Rio
}

\section{ABSTRACT}

Despite the alleged benefits of $\mathrm{m}$-banking, its acceptance has been short of industry expectations. One plausible explanation may be consumers' initial lack of trust in available services. The objective of the study is to investigate the effect of trust in the intention to use $m$-banking in the Brazilian context, specifically among users of the city of Rio de Janeiro. Therefore, we developed and tested a model that relates trust and its antecedents (familiarity, ease of use, perceived usefulness, safety, privacy and innovativeness) with the intention to use m-banking. We got a sample of 272 users of financial mobile apps and through structural equation modeling the hypotheses were tested. The results confirmed most of the proposed hypotheses, and we found significant relationships between the construct trust and other constructs, which significantly influence the intended use of banking services via m-banking.

Keywords: TAM model; Technology acceptance; m-banking; Trust.

\section{INTRODUCTION}

The use of mobile devices such as smartphones and tablets is transforming the interaction of people and enterprises through the growing offer of information and services termed as mobile services (CYBIS; BETIOL; FAUST, 2007). An important aspect of this type of service is the fact that this channel allows the individual to have access to service e and at anytime, which ends up allowing an intense relationship between the company and its customers (CARLSSON; WALDEN; BOWMAN, 2006).

One of the offered services that grow the most through the use of mobile devices is mobile banking (m-banking) (CRUZ et al., 2010; HANAFIZADEH; KHEDMATGOZAR, 2012; FEBRABAN, 2013). The use of $\mathrm{m}$-banking has been growing each year, in line with the

\footnotetext{
Corresponding author:

† Pontifícia Universidade Católica do Rio de Janeiro PUC-Rio

E-mail: leaoramos@gmail.com

$\Omega$ Pontifícia Universidade Católica do Rio de Janeiro PUC-Rio

E-mail: jorgebf@gmail.com

${ }^{\sharp}$ Unigranrio - Universidade Grande Rio

E-mail: angilberto.freitas@gmail.com

* Pontifícia Universidade Católica do Rio de Janeiro PUC-Rio

E-mail: juwrnck@gmail.com

Received: 04/26/2016

Revised: 07/19/2016.

Accepted: 04/13/2017

Published Online: 02/15/2018
} 
increasing adoption of smartphones. This growth was already perceived in 2012 when surveys showed that $53.4 \%$ of consumers considered m-banking as a fundamental and essential prerequisite in relation to banking services (Datamonitor's Financial Services Consumer Insight Surveys, 2013).

In the Brazilian context, which has one of the most advanced banking systems in the world, m-banking is offered by practically all banks (FEBRABAN, 2013). More than half of the banking transactions (52\%) carried out in 2014 were done via m-banking and the internet. Furthermore, according to a study by Febraban published in 2015, 47\% of active accounts in Brazil make use of m-banking, totaling around 51 million accounts (FEBRABAN, 2014). According to this study, despite the observed growth, there are still opportunities to be explored in the area, since mobile and internet banking services account for only $20 \%$ of total transactions with financial transactions (FEBRABAN, 2014).

However, in order to propose strategies that increase the use of $m$-banking, we need to understand the factors that facilitate and inhibit its use. One of the key critical factors identified for the adoption of mobile devices for banking transactions is trust (SIAU; SHEN, 2003; GU; LEE; SUH. 2009; KIM; SHIM; LEE, 2009; LEE; CHUNG, 2009 CHIAN SON-YU, 2015, AFSHAN; SHARIF, 2016). According to McKnight, Choudhury and Kacmar (2002), trust has a significant impact on the intention to use services in virtual environments by end consumers, due to its role in reducing uncertainty. Ashan and Sharif (2016) in turn, argue about the importance of trust in using m-banking by linking initial trust to behavioral intentions of use and expectations of effort and performance. The authors raise issues such as concern for security and privacy in the mobile environment and suggest the importance of clear communication that encourages the development of initial trust and motivates users to use this type of service. Among the factors that most collaborate in the development of initial trust to use m-banking, the authors emphasize in their research the "structural guarantee", in which the bank clearly and objectively stipulates and communicates rules that safeguard security, confidentiality, policies and guarantees to consumers that choose to use the m-banking service (AFSHAN; SHARIF, 2016).

The online environment is an impersonal environment that offers numerous risks due to viruses, Trojans and other types of threats characteristic of this setting. In this sense, in an online service that involves financial transactions, such as m-banking, these factors can contribute to increase the insecurity and risk perceived by users who consider making payments and banking transactions over the internet. Different from other contexts, in an environment in which financial transactions take place, there is a greater perception of perceived risk, which increases the importance of trust (AFSHAN; SHARIF, 2016). Given this greater perception of risk, we can infer that trust plays a leading role in understanding the intention of using m-banking by the individual, since, from the management point of view, if processed well, it can reduce the uncertainties of the user, positively influencing their intended use (ZHOU, 2011B; CHIAN SON-YU, 2015; MALAQUIAS; HWANG, 2016; AFSHAN; SHARIF, 2016).

In view of the above scenario, and despite the importance of the banking sector for the Brazilian economy, besides the fact that m-banking is already a reality, a search on the SPELL ${ }^{1}$ site in October 2015 pointed to only two studies that evaluate the use of this service in Brazil. The first study, by Ramos, Pimenta and Rodrigues (2010), which

\footnotetext{
${ }^{1}$ The Spell (www.spell.org.br) - Scientific Periodicals Electronic Librar - is a system of indexing, research and free availability of scientific production in the areas of Administration, Accounting and Tourism.
} 
BBR

15,2

177

analyzed the perceptions of consumers regarding the adoption of m-banking in light of the Theory of Diffusion of Innovations (ROGERS, 2003), identifying that non-adopters have more of a negative view of the attributes of innovation (relative advantage, observability, compatibility, testability and complexity). The second research, by Santos, Veiga and Moura (2010), chose to test the Theory of Planned Behavior (TAYLOR; TODD, 1995), and identified security as one of the main aspects in adopting the service. However, neither work dealt with the aspect of trust.

However, in searches using Google Scholar, for research carried out in the last five years in Brazil, we found two articles from the year 2010: (1) the study by Cruz et al. (2010), which sought to investigate the perceived obstacles to the use of m-banking, including the concept of trust in the category "perceived risk", a category that was observed to be the main obstacle to the use of this service; and (2) the study by Mazzon and Hernandez (2010), which deals with the theme from the perspective of adoption in face of the framework proposed by the authors who seek to integrate aspects of previously proposed theories such as the theory of diffusion of innovations (ROGERS, 2003), the technology acceptance model - TAM - (Davis, 1989), diffusion of information technology innovation among organizations (MOORE; BENBASAT, 1991) and the theory of information technology adoption (TAYLOR; TODD, 1995). Despite the extensive theoretical framework, this article does not specifically address the concept of trust and its antecedents. In view of this scenario, what we perceive is that, although the theme has already been studied in other cultures and presented significant results (LUO et al, 2010; LIN, 2011), the articulation of the "trust" construct is still under-explored in the Brazilian context. Thus, as we believe that trust plays a paramount role in the consumer's behavior in adopting m-banking and due to the gap found in the Brazilian literature on the effects of trust in the intention to use it, this study seeks to identify the influence of trust in the intention to use m-banking in the Brazilian context, taking users of the city of Rio de Janeiro as a sample (RJ).

In addition to the lack of publications related to the study of the use of m-banking in the Brazilian scenario, making it difficult to assess the difference between the Brazilian market and other markets, there is a perception that perceived risk is one of the barriers that most contribute to the reduced use of m-banking in Brazil (MALAQUIAS; HWANG, 2016). Therefore, the study of the interference of trust in the intention to use m-banking in this market becomes relevant, since it is important for businesses to take such factors into account to improve customer relationship and the use of offered services.

\section{LITERATURE REVIEW}

\section{MobILE BANIKING}

Banks are becoming increasingly "mobile", with access available at anywhere and at any time, as a result of the advancement of new information and communications technologies (ICTs) (SHAIKH; KARJALUOTO, 2015). One of the services born from these technologies is mobile banking, or m-banking, which is considered the third technological revolution in customer service (GOUVEIA, 2007) and has represented an important channel of relationship with customers (FEBRABAM, 2013).

Conceptually, m-banking can be described as a set of banking services offered through the use of a mobile device, connected to a mobile internet network or data plan, which 
enables users to make payments and perform virtually any banking transactions linked to the current account without the participation of bank employees (GARTNER, 2009; HANAFIZADEH; KHEDMATGOZAR, 2012).

The m-banking service includes full access to bank transactions and details of the current account, credit cards, payments, transfers of securities, applications in an investment account etc. The use of the mobile app does not generate expenses for the consumer, and the only cost to use m-banking is the transmission of data to the telephone operator if it is not connected to a Wi-Fi network (AL-JABRI; SOHAIL, 2012).

\section{TECHNOLOGY ADOPTION}

Several models have been applied to evaluate the acceptance of technology, with the ones mostly used being the Theory of Reasoned Action (TRA) by Fishbein and Ajzen (1975), which served as a basis for other models such as The Theory of Planned Behavior (TPB) (AJZEN, 1991), the Technology Acceptance Model (TAM) by Davis, Bagozzi and Warshaw (1989), the Model of the Information Technology Diffusion Process (STRAUB, 1994), The Theory of Decomposed Planned Behavior (Taylor and Todd, 1995) the Unified Theory of Acceptance and Use of Technology (UTAUT) (VENKATESH et al., 2003) and the Unified Theory of Acceptance and Use of Technology 2 (UTAUT 2) (VENKATESH; THONG; XU, 2012). In addition, the Diffusion of Innovations Theory (ROGERS, 2003), although it is not derived from TRA, has also been widely used to assess the acceptance of technologies in light of the attributes it utilizes to characterize innovations (relative advantage, compatibility, observability, complexity and testability).

Of the models above, one of the most used has been the TAM (DAVIS; BAGOZZI; WARSHAW, 1989), due to its parsimony and explanatory power (KULVIWAT et al., 2007). According to Davis et al. (1989), the acceptance of the technology, or the intention to use it, is influenced by the behavioral intention, which in turn, is formed by two cognitive evaluations: (1) the perceived usefulness; and (2) the ease of use. The first argues that the use of a certain computational technology (the use of some kind of software or information system) will improve the person's performance in their job. The second proposes that the use of the evaluated technology will be free of effort.

The model infers that the perceived ease of use directly affects perceived usefulness, and both influence the attitude that an individual will have on the intention to use a particular system. The perceived usefulness and attitude regarding the use affect the behavioral intention of use, that is, the intention to use the system in the future, which will determine the actual use of the system. To increase the explanatory power of the TAM, Davis, Bagozzi and Warshaw (1989) proposed the possibility of including external factors prior to people's cognitive evaluations, attitudes and intentions.

With regard to the application of these models for m-banking research, the literature shows a growing interest in investigating the theme (LUARN; LIN, 2005; RIIVARI, 2005; SUORANTA; MATTILA, 2004, LEE; KANG; MCKNIGHT, 2007; SULAIMAN; JAAFAR; MOHEZAR, 2007; GU; LEE; SUH, 2009; LIN, 2011; RAMOS; PIMENTA; RODRIGUES, 2010; SANTOS; VEIGA; MOURA, 2010; HANAFIZADEH; KHEDMATGOZAR, 2012; HANAFIZADETH, et al., 2014). Sulaiman, Jaafar and Mohezar (2007) suggest that Rogers's (2003) Diffusion of Innovations Theory is one of the most suitable in the study of the adoption

of m-banking. In contrast, Luarn and Lin (2005) and Pedersen (2005) believe that the TAM is 
BBR

15,2

179

the model that best applies to the context of m-banking. In general, all of these studies seek to identify which factors have the greatest effect on the intention to use m-banking. Thus, listed below are the most influential factors found in the literature that affect the consumer's decision to accept new technologies together with the hypotheses of the proposed model to evaluate the intention to use m-banking in the Brazilian context.

\section{TRUST}

In the virtual world, anonymity and temporal and spatial separation in online transactions involve great uncertainties and risks. Therefore, users need to build trust to mitigate perceived risk and thus facilitate their transactions (ZHOU, 2011a). According to Mayer, Davis and Shoorman (1995), trust can be understood as the desire of one of the parties of being vulnerable to the actions of another party based on certain expectations of how this second party, to which the trust is directed, will act in a given situation. According to the authors, the previously mentioned vulnerability is related to a pre-disposition to take risks, considering that something important may be lost. Rotter (1967) defines trust as an individual expectation that another individual's word is trustworthy. Thus, trust would be the willingness of one party to accept vulnerability, but with the expectation that one can rely on the other party (MORGAN; HUNT, 1994).

In the context of e-commerce, trust has been widely investigated and received considerable attention from the literature (BELDAD; DE JONG; STEEHOUSER, 2010). Similar to online transactions, mobile transactions also involve large risks. Thus, the construction of mobile user trust is critical (VARNALI; TOKER, 2010) so that the individual is prone to use the service. However, compared to the abundant research on online trust, mobile trust is only beginning to receive attention (ZHOU, 2011a).

Siau and Shen (2003) observed that mobile trust is affected by factors associated with two aspects: supplier and mobile phone technologies. According to Li and Yeh (2010), application design affects trust in mobile technology through ease of use, perceived usefulness and customization. Vance, Christophe and Straub (2008) examined the effect of system quality, including visual appeal and navigation structure, as factors that affect user trust in the mobile environment.

Considering the impersonality of the online environment and the large number of threats present in this scenario (errors in transactions, viruses, phishing, hackers, etc.), we have a greater perception of risk, which diminishes the intention to use, making trust play a fundamental role to mitigate fears of this nature (WANG et al 2015; MALAQUIAS; HWANG, 2016). Therefore, trust is believed to be an important antecedent of use intention of digital financial systems, such as m-banking (SHAIKH; KARJALUOTO, 2015).

Articulating the trust construct further, the study performed by Dimitriadis and Kyrezis (2010) addresses the concept of trusting beliefs, which are described by means of four distinctive elements: (1) competence - the belief that the other party has the ability or power to do what needs to be done; (2) benevolence - the belief that the other party cares and is motivated with the other; (3) integrity - the belief that the other party makes good faith agreements, tells the truth, acts ethically, and keeps promises; and (4) predictability the belief that the actions of the other party are consistent over time and can be predicted in certain situations. For authors, the "trusting beliefs" would be the cognitive and affective aspects of the trust construct and "trusting intention" would be the behavioral component of trust. Mayer, Davis and Shoorman (1995) map out in their study three of the factors cited above as those that explain most of the trust or, rather, of the trusted party, and they are: ability (which can be understood as competence/skill), benevolence and integrity. 
Transposing these concepts into the context of m-banking, competence refers to the individual's belief and the perception of the individual that managers of m-banking companies have the competence, ability and knowledge to understand their needs while managing their personal finances. Benevolence is the belief that one has the perception that bank executives care about them and act on their behalf. Integrity is the belief of the subject's perception that the company follows a set of principles usually cultivated by responsible people (MCKNIGHT; CHOUDHURY; KACMAR, 2002). The perception of competence, benevolence, and integrity in m-banking can play an important role in determining individual attitudes to use the application. Furthermore, several other factors also influence the construction of trust. Familiarity, perceived usefulness, perceived ease of use, privacy, security and innovation are factors that have been pointed out as important antecedents to trust.

\section{FAMILIARITY}

Familiarity refers to a person's knowledge of a given technology and the experience they have with it - in the case of the present study, m-banking. According to Gefen (2000), familiarity is one of the factors that directly or indirectly influences the use intention of the Internet for both information and transaction purposes. It has been studied as a control variable in the relationship between trust and use intention (GEFEN; STRAUB, 2004). The impact of familiarity on the willingness to perform transactions through mobile channels has also been supported in a context of retail Internet banking (BHATTACHERJEE, 2002).

In addition, according to Luhmann (1979), familiarity is a requirement for trust as it assists the individual in understanding the environment within which expectations of trust can be explained. Gulati (1995) argues that familiarity helps build trust since it not only provides a framework for future expectations, but also enables people to come up with concrete ideas about what to expect based on previous interactions. The reason for this is that familiarity measures the degree to which previous experience was understood.

Afshan and Sharif(2016) also analyzed the direct and positive relationship that familiarity has on trust in their study, showing the direct link between these constructs.

The study by Gefen (2000), reports that in many cases, prior experience is the basis of trust, with familiarity possibly creating trust when the experience was favorable or ruining it if the experience were unfavorable. Thus:

\section{H1: Familiarity has a direct and positive effect on trust in m-banking.}

\section{Perceived USEFulness}

The construct perceived usefulness expresses how much an individual considers that a technology can improve their productivity or performance in a given task (DAVIS; 1989). Such a definition refers to the consumer's perception of the use of banking applications via mobile devices in relation to the improvement of the result, making the experience of performing a financial transaction more efficient. This perception positively influences the intention to trust the use of m-banking, with the trusting intention being the behavioral aspect of the "Trust" construct (DIMITRIADIS; KYREZIS, 2010).

According to Afshan and Sharif (2016), individuals will adopt a particular technology if they perceive it as useful in performing a daily task, and will not adopt it in case it does not result any improvement in these tasks. Therefore, we constitute the following hypothesis: 


\section{Perceived EASE OF USE}

The perception of ease of use is one of the main components of the TAM. It is defined as the belief that the individual forms regarding the absence of effort in learning to use a new technology. The greater the perception of m-banking's ease of use, the more positive the consumer's attitude will be towards the technology.

Because of restrictions on mobile devices, such as small screens, for example, it may be difficult for the user to operate m-banking services if service providers do not offer them a good interface. An easy-to-use m-banking app with a good interface and intuitive navigation would reflect the competence and benevolence of service providers, which would affect consumer trust. In addition, a simple mobile banking system would also reduce the time spent by the user to learn how to use the m-banking service and increase their sense of control over the application. This would help the consumer to focus on the main activity, which is to make financial transactions, improving their experience. The effect of perceived ease of use on trust was validated in previous studies (BENAMATI et al., 2010; VANCE; CHRISTOPHE; STRAUB, 2008). Thus:

\section{H3: Perceived ease of use has a direct and positive effect on trust in m-banking.}

\section{SECURITY}

Perceived security is the user's perception that the service provider will meet safety requirements such as authentication, integrity, and encryption (KIM; FERRIM; RAO, 2008).

The customer's perceived security when carrying out online transactions depends on how one understands the level of security measures taken by the seller (FRIEDMAN; KHAN JR, 2000). When a user finds security features and protection mechanisms (encryption, protection, SSL authentication, etc.) on the bank's website and specifically in the m-banking application, one can recognize the seller's intent to ensure the security requirements needed during online transactions (CHELLAPPA; PAVLOU, 2002). This would help the customer to make a purchase decision, since all of the above mentioned artifacts emphasize that the seller is making efforts to gain the consumer's trust, reducing their risk perception. Therefore, the user's security perception would increase trust towards the supplier, in this case, the banks.

On the other hand, many customers believe that online payment channels are not secure and can be intercepted (CRUZ et al., 2010; LA POLLA; MARTINELLI; SGANDURRA, 2013). This would reduce their trust level by discouraging them from carrying out online banking transactions. Therefore:

H4: Perceived security has a direct and positive effect on trust in m-banking.

\section{Privacy}

Perceived privacy is the perception that the supplier will try to protect the consumer's confidential information, collected during electronic transactions, and not to make unauthorized use or disclosure of such (KIM; FERRIM; RAO, 2008). 
In online trading, during a transaction, the seller collects varied personal information such as name, e-mail, phone number and home address of the buyer (SWAMINATHAN; LEPKOWSKA-WHITE; RAO, 1999). In a bank transaction, in addition to the personal data of any transaction, information of bank statements, credit cards and investments is available, which, in the wrong hands, can jeopardize the user (MUKHERJEE, NATH, 2003). Thus:

\section{H5: Perceived privacy has a direct and positive effect on trust in m-banking.}

\section{INNOVATIVENESS}

Innovativeness is the tendency for an individual to be a pioneer in adopting new technologies or being an opinion leader in relation to technology (AGARWAL; KARAHANNA, 2000; ROGERS, 2003).

According to Rogers (2003), individuals with greater innovativeness are able to cope with higher levels of uncertainty and develop more positive intentions regarding the acceptance of an innovation, such as a m-banking application. Therefore, users with high innovativeness are more likely to experience m-banking (MONTEZEMI; SAREMI, 2015). For being openminded about new technologies and by having a more positive attitude to take risks, such individuals tend to quickly build trust in m-banking (ZHOU, 2011a). Therefore:

H6: Innovativeness has a direct and positive effect on trust in m-banking.

\section{USE INTENTION}

The use intention expresses the discreet probability of the consumer to use something specific in a period of time (DIMITRIADIS; KYREZIS, 2010). Based on models such as TAM (DAVIS; BAGOZZI; WARSHAW, 1989), TRA (FISHBEIN; AJZEN, 1975) and TPB (AJZEN, 1991), many e-commerce surveys have demonstrated that use intentions involving online transactions are a significant predictor of effective consumer participation in the operations (PAVLOU; FYGENSON, 2006). The relationship between intention and behavior is based on the assumption that human beings make rational decisions based on the information they have. Thus, the behavioral intention of a person to perform a behavior is the immediate determinant of the actual behavior of the person (FISHBEIN; AJZEN, 1980).

Pennington, Wilcox and Grover (2003) have suggested that consumers perceive the technical competence of a website in accordance with the understanding of the processes governing online transactions. If clients believe that banks possess the competence, skills and experience to provide adequate transactional services, such consumers are more likely to evaluate mobile banking services favorably, increasing trust in online transactions, which positively affects the intention to use m-banking. On the other hand, according to Afshan and Sharif (2016), trust plays a preponderant role in an e-commerce and m-commerce environment, due to the high degree of uncertainty and associated risks between the parties involved. Thus, trust becomes a factor related to the intention and use of m-banking. Therefore:

\section{H7: Trust has a direct and positive effect on the intention to use m-banking.}

Figure 1 illustrates the discussed hypotheses and the proposed theoretical model. 
BBR

15,2

183

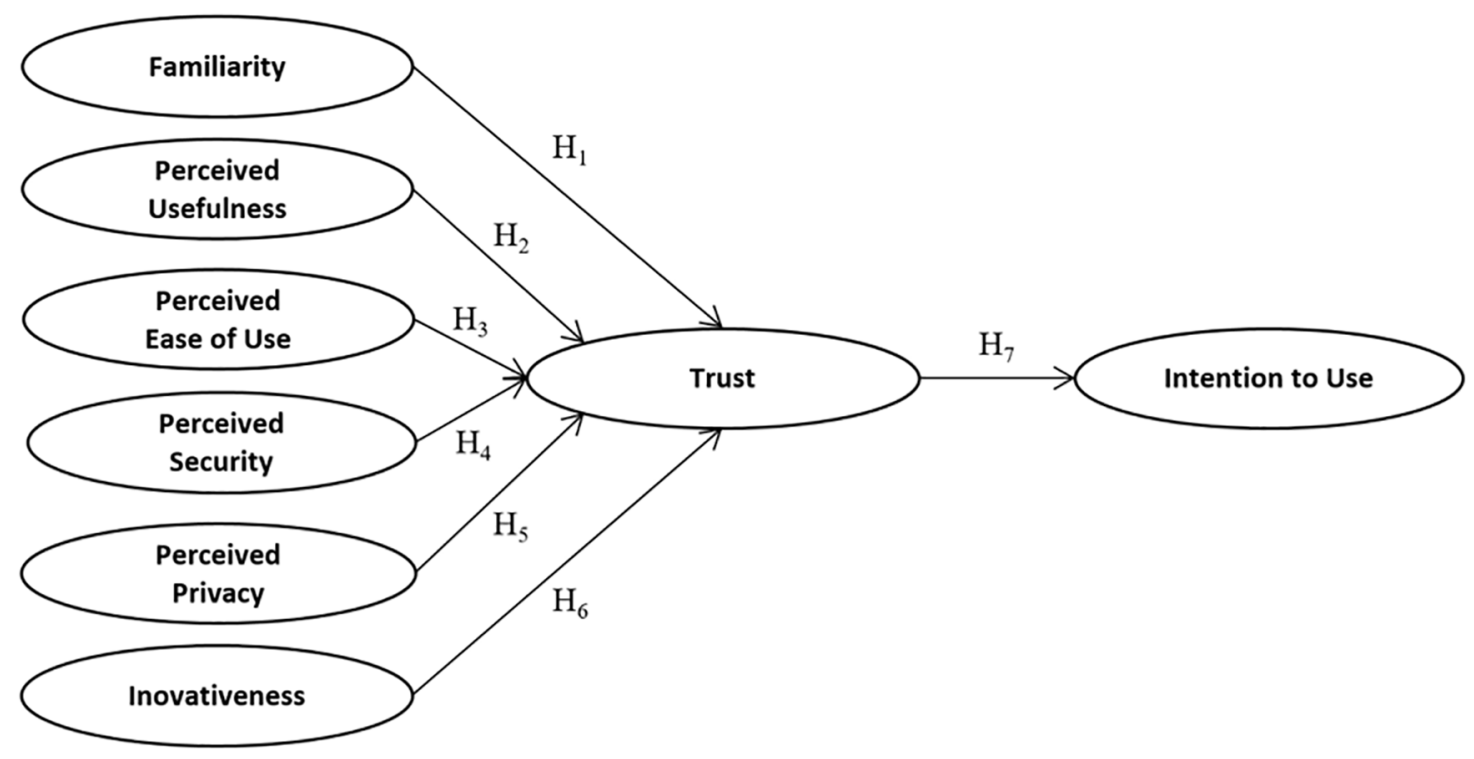

Source: Adapted to the Brazilian context based on DIMITRIADIS; KYREZIS (2010).

Figure 1. Proposed model.

\section{METHODOLOGY}

To test the hypotheses, we conducted a cross-sectional survey (PARASURAMAN; GREWAL; KRISHNAN, 2006) with a non-probabilistic sample of the population of interest. Most studies on consumer technology acceptance use this same form of research (KULVIWAT et al., 2007), with structured questionnaires being presented to consumers at a single moment in time. The treatment of data for the hypothesis test was done through Structural Equations Modeling in which we used scales elaborated and tested in the literature for the measurement of all the constructs (Table 1).

The items included in the research instrument were translated into Portuguese by professionals, with translation and back-translation stages applied to ensure that the scales in Portuguese were as close as possible to the original scales. We performed a pre-test of the questionnaire to evaluate the respondents' understanding of the research instrument. After the pre-test, we developed the final research instrument, which had a total of 41 items measured by five-point Likert scales, in addition to nine items related to demographic and behavioral variables.

The studied population was Brazilians residents in Rio de Janeiro, in the possession of a mobile device, who had a bank account and who had already used m-banking. The data were obtained through a self-administered questionnaire (AAKER; KUMAR; DAY, 2006), whose link the participants received via e-mail or social networks.

Table 1. Constructs with their said scales.

\begin{tabular}{|lcc|}
\hline Familiarity & 3 items & Griffn; Babin; Attaway, 1996 \\
Perceived usefulness & 4 items & Davis, 1989 \\
Perceived ease of use & 4 items & Davis, 1989 \\
Security & 4 items & Jarveenpaa, Tractinsky and Vitale, 2000 \\
Privacy & 4 items & Jarveenpaa, Tractinsky and Vitale, 2000 \\
Innovativeness & 5 items & Oliver; Bearden, 1985; Goldsmith; Hofacker, 1991 \\
Trust & 15 items & Mcknight; Choudhury; Kacmar, 2002; Mcknight; Chervany, 2002 \\
Use intention & 2 items & Dimitriadis; Kyrezis, 2010 \\
\hline
\end{tabular}


We obtained a sample with 346 respondents. Of these, 74 were eliminated because they had missing data or were filled incorrectly. The final sample consisted of 272 valid questionnaires. Of this total, 121 respondents (44\%) are married; 114 (42\%), single; and $37(14 \%)$ have another civil status. In relation to the average family income, 149 participants (55\%) have monthly family income over 10,000 BRL; 59 (22\%), between 6,000 and 10,000 BRL; 30 (11\%), between 3,501 and 6,000 BRL; $27(10 \%)$, between 2,000 and 3,500 BRL; and only 1 (2\%), bellow 2,000 BRL. Most respondents (47\%) were aged between 31 and 40 years, followed by $21 \%$ aged between 41 and 50 years.

\section{RESULTS}

\section{Measurement Model}

We performed a confirmatory factor analysis (CFA) to test the validity, unidimensionality and reliability of the scales used in the measurement model. After refinement of the model, in which 8 items were removed (1 of usefulness, 1 of privacy, 1 of security, 1 of familiarity, 2 of innovativeness and 2 of trust), the final measurement model was composed of 33 items and presented fit indices considered as good, with the RMSEA 0.051, CFI 0.92, IFI 0.92, and TLI 0.91. Assessed jointly, the final indices suggest a satisfactory fit of data for the proposed model (HU; BENTLER, 1999).

The face validity for all scales was guaranteed during the development of the research instrument (choice of scales already used in the literature, careful translation and pretests). To verify the nomological validity, we analyzed the correlation matrix between the constructs, with all correlations being significant and in the expected direction. In relation to the convergent validity, we calculated the average variance extracted for each construct (AVE). All AVE values were between 0.59 and 0.73 , evidencing the convergent validity of the scales used. Regarding the internal consistency and reliability of the scales, all met the minimum levels of reliability considered adequate by the literature (FORNELL; LARCKER, 1981), with all values ranging from 0.72 to 0.90 for the alpha coefficient and from 0.71 to 0.90 for composite reliability. Finally, all the shared variances were lower than the variance extracted by the items that measure the constructs, indicating adequate discriminant validity.

\section{Structural Model}

Regarding the structural model, all indices indicated a good fit of the model to the data. The ratio $\chi 2 /$ d.f. was 2.63 . Incremental goodness-of-fit indexes were greater than 0.90 , with CFI 0.91, TLI 0.90 and IFI 0.91. The absolute fit indices presented values below the limit of 0.08 established by the literature (HU; BENTLER, 1999), also indicating a good fit of the model. The RMSEA was 0.064 (C. I. from 0.057 to 0.068 ) and the SRMR was 0.069. Given the presented indices, we concluded that the fit of the model was satisfactory.

After checking the fit of the measurement and structural models, we evaluated the coefficients estimated for the causal relationships between the constructs (Table 2). The verification of each of the hypothesis of the research was carried out with the analysis of the magnitude, direction and significance of the standardized coefficients estimated by means of the structural model. Except for hypothesis 7, all others were verified.

\section{Discussion OF RESUltS}

In the proposed model, thirteen items measured the trust construct, with the results indicating a good fit of the model and providing evidence of the relevance of the proposed 
BBR

15,2

185

Table 2. Standardized coefficients estimated for the model.

\begin{tabular}{lccc}
\hline Proposed relationship & Standardized Coefficient & p-value & Hypothesis Verified \\
\hline H1: Familiarity $\rightarrow$ Trust & 0.10 & 0.048 & Yes \\
H2: Perceived usefulness $\rightarrow$ Trust & 0.13 & 0.011 & Yes \\
H3: Perceived ease of use $\rightarrow$ Trust & 0.15 & 0.005 & Yes \\
H4: Perceived Security $\rightarrow$ Trust & 0.60 & $<0.001$ & Yes \\
H5: Perceived Privacy $\rightarrow$ Trust & 0.43 & $<0.001$ & Yes \\
H6: Innovativeness $\rightarrow$ Trust & -0.04 & 0.938 & No \\
H7: Trust $\rightarrow$ Use Intention & 0.73 & $<0.001$ & Yes \\
\hline
\end{tabular}

Source: research data.

relations. Regarding the seven hypotheses tested in this study, six were tested with a significance level of 0.05 or lower. The proposed model was able to explain $60.5 \%$ of the variability of the trust construct and $53.4 \%$ of the variability of the use intention, indicating that the antecedents evaluated are able to explain a good part of consumers' trust and use intention with respect to m-banking services.

The first hypothesis, H1, pointed out that familiarity had positive and direct impact on trust. We can infer that consumers more familiar with banking applications tend to trust the channel. By analyzing the data, we observed that $31 \%$ of the respondents reported that they knew their bank's m-banking service through the bank's institutional campaigns; $15 \%$, through the media; and $12 \%$ were presented to it by the manager of their account. We can assume that more than $50 \%$ of the respondents had access to information to get to know their bank's m-banking solution and feel familiar with it, and this would have contributed to a positive impact on trust in m-banking.

In the case of $\mathrm{H} 2$, the study also indicates that there is a positive and direct relationship between usefulness and trust. We can infer that the consumer who perceives the usefulness of m-banking tends to have their trust positively affected. Considering the current lifestyle of consumers, characterized by a constant concern with time, which is increasingly scarce, it is understood that there is a greater perception about the usefulness of applications that optimize time, i.e., of technologies that can improve individual productivity and performance. This agrees with the study by Davis, Bagozzi and Warshaw (1989), which indicates that the perception of usefulness is a factor that can lead the individual to use a new technology.

As for H3, it is also confirmed, indicating that the ease of use positively affected trust and, indirectly, the use intention, corroborating the results of studies such as Zhou (2013) and Hanafizadeh et al. (2014). That is, the easier the handling of $\mathrm{m}$-banking services, the greater the user's propensity to rely on the app. Ease is a perception that human beings have that they will expend little effort to perform a particular task. By observing the data, we verified that respondents aged 31 to 40 correspond to $47 \%$ of the sample and participants younger than 30 years of age, 18\%. We can infer that more than half of the participants grew in the age of computers, suggesting that these users find it easy to deal with new technologies such as m-banking. Another fact that may have influenced the results is the fact that $55 \%$ of respondents stated that they had a family income above ten thousand BRL. Usually, the greater the purchasing power, the greater the chances that these people will have a higher degree of schooling, which may also reduce the perception of some difficulty in using m-banking. In addition, the smaller the effort to learn how to handle the application, the greater will be the acceptance of it, thus justifying the confirmation of $\mathrm{H} 3$. 
In the case of security, consumers who have the perception that the application gives them security have shown greater trust in m-banking, confirming H4, where there was a positive effect of security on trust. We can assume that in the user's perception, if the application is secure and is on a trustworthy platform, the sense of security in using the application leads one to trust in m-banking. These results resemble those by Dimitriadis and Kyrezis (2010) and by Hanafizadeh et al. (2014), in which security is one of the antecedents that positively impact trust. The fact that $\mathrm{m}$-banking applications are available on official platforms with which the user has already established a trust relationship, as in the case of Apple's App Store customers, can assist in forming the perception of security regarding this channel of relationship with the bank. Another assumption that can be made is that the perception that the device is always with the person gives them a sense of security, since, in most cases, he/she is the only user.

According to $\mathrm{Wu}$, Huang and $\mathrm{Hsu}$ (2013) and McKnight and Chervany (2002), privacy is one of the barriers to consumer acceptance of online transactions. However, in contrast to the research by $\mathrm{Wu}$, Huang and Hsu (2013), in the present study, it had a positive effect on trust (H5). One possible explanation suggests that participants' perception of privacy actually has a direct and significant effect on trust, illustrating that, users who feel secure in protecting their data and privacy tend to trust more in online applications and transactions.

In relation to $\mathrm{H} 6$, innovativeness did not present direct and significant effects on trust, indicating that trust in m-banking would not be related to the degree of consumer innovativeness. The fact that this hypothesis was rejected corroborates the results obtained in the study by Dimitriadis and Kyrezis (2010), in which the classification of innovativeness of respondents had no impact on trusting the new technology. A possible explanation for the results found here is that, for the most part, the participants in this study are young people, younger than 40 years of age, with high schooling levels and high purchasing power, i.e., with greater propensity for innovation (innovativeness of the research participants, in an aggregated way, presented a high mean of 4.00 on a scale of 1.00 to 5.00 , with a very low standard deviation of 0.23 ). This may have generated a perception that m-banking would not be such a new technology and, therefore, the degree of innovativeness of respondents did not have a significant effect on trust.

Another possible analysis for this result is that the tendency to innovativeness that an individual presents, in the context of the adoption of mobile banking and phone banking transactions, is not related to trust. In this case, other factors such as security and privacy weigh more as antecedents, since the experience in the use of mobile banking, if negative, can have unpleasant consequences, reducing the intention to experiment with a certain technology only by the propensity to innovativeness, corroborating with the finding also by Zhou (2011b).

Finally, H7 pointed out that trust positively and directly impacts the use intention of m-banking. This corroborates studies that speak of the direct and positive relationship between trust and use intention by consumers (MCKNIGHT; CHERVANY, 2002; DIMITRIADIS; KYREZIS, 2010; KIM; SHIM; LEE, 2009). The confirmation of H7 aligns with the arguments by Marett et al. (2015), which postulates that the consumer builds their trust beliefs based on the institutions that they relate with. When such beliefs are positively reinforced, they directly influence their trusting intention, thus reinforcing trust and subsequently their intention and/or attitude of using the service. Based on the study by Marett et al. (2015), it can be said that, if the respondent has a positive belief in relation to their bank, they present an intention to trust in their m-banking and, therefore, this will positively affect their intention to use the application. 
BBR

15,2

187

\section{CONCLUSIONS}

This research presents important results that may be useful for the banking sector. Its major contribution is in the development of the understanding of consumer behavior of m-banking and of how trust antecedents influence the intention to use banking services through mobile devices in the national context.

The results and relationships represent a step forward in understanding the theory of technology acceptance and research on mobile banking applications, bringing various theoretical implications. The research confirmed the importance of the relationship between consumer trust and the use intention of banking application.

Responding to the questions listed at the beginning of this study, we can conclude that trust does indeed affect the consumer's intention to use m-banking, being influenced by perceived ease of use, perceived usefulness, security, privacy, and familiarity.

However, innovativeness did not have a direct impact on trust. The fact that the individual's degree of innovativeness has not affected trust may be related to the study's actual limitation. We also conclude that the use intention is related more specifically to individual experiences such as trust, familiarity and security.

The present study indicates that, as trust plays a considerable role in the consumer's use intention (DIMITRIADIS; KYREZIS, 2010; ZHOU, 2011b; MONTEZEMI; SAREMI, 2015; WANG et Al, 2015), banks should encourage the creation and maintenance of trust, such as privacy and security policies for the application (LUARN; LIN, 2005; ZHOU, 2011b; HANAFIZADEH et al., 2012).

M-banking is considered a channel for the provision of banking services with facilities and low costs, even for underdeveloped countries (ANDERSON, 2010; HANAFIZADEH et al., 2014, MOHAMMADI, 2015). Therefore, investigating the user's perceptions regarding the process of trust and its effects on use intention, identifying which attributes influence their perception regarding security, ease of use, usefulness and privacy can help executives analyze their own mobile services to identify the strengths and weaknesses of their applications.

From the management point of view, the results provide support for investment decisions related to the development of more efficient and secure banking applications, taking into account the concerns and desires of consumers.

The limitation of this study concerns the collection and treatment of data. Regarding the external validity of the results, the data only reflect the study population: Brazilians belonging to the $\mathrm{A}$ and $\mathrm{B}$ socioeconomic classes, who have a mobile device, have a bank account and have already performed financial transactions through a mobile device. For a greater understanding of the use of these m-banking applications, one should check with other segments as in classes $\mathrm{C}$ and $\mathrm{D}$ and with profiles of users different from this study, in addition to those who say they are not m-banking users to identify other factors that inhibit their use.

Future research can verify the influence that the bank's brand has on the user and their trust in using m-banking, besides evaluating possible effects of moderators such as gender and level of schooling on the relations observed in the proposed model. Moreover, according to $\mathrm{Yu}$ (2012), men and women present differences in the perceptions of financial costs and expectation of performance in the use of m-banking. Therefore, future research can verify how the gender moderator influences the proposed trust relationship. Finally, another moderator that could be used is the mobile operating system. La Polla et al (2013) argue that the operating system of mobile phones may be a factor influencing the use of 
mobile phones for transactions that involve financial risk. With the Apple's system, the iOS, being a closed platform, it is known to be less vulnerable to attack than the Android system and the Microsoft Windows Phone system, thus the verification of the operating system as moderator should also be evaluated in the process of acceptance of $\mathrm{m}$-banking by the individual.

\section{REFERENCES}

AAKER, D.; KUMAR, V.; DAY, G.Marketing research. 9. ed. New York Wiley, 2006.

AFSHAN, S.; SHARIF, A. Acceptance of mobile banking framework in Pakistan. Telematics and Informatics, v. 33, n. 2, p. 370-387, 2016.

AGARWAL, R.; PRASAD, J. A field study of the adoption of software process innovations by information system professionals. IEEE Transactions on Engineering Management, v.47 n.3, p.295-308, 2000.

AJZEN, I. The theory of planned behavior. Organizational Behavior and Human Decision Processes, v.50, n.2, p.179-211, 1991.

AJZEN I.; FISHBEIN, M. Understanding attitudes and predicting social behavior. Local: Prentice Hall; Englewood Cliffs, 1980.

AL-JABRI I. M.; SOHAIL, M.M-banking adoption: application of diffusion of innovation theory. Journal of Electronic Commerce Research, v.13, n.4, 2012.

ANDERSON, J. M-banking in developing markets: competitive and regulatory implications. Info, v.12, n.1, p.18-25, 2010.

BELDAD A,; DE JONG M,; STEEHOUSER M. How shall I trust faceless and the intangible? A literature review on the antecedents of online trust. Computers in Human Behavior, v.26, n.5, p.857-869,2010.

BENAMATI, J.; FULLER M.; SERVA, M.; BAROUDI, J.Clarifying the integration of trust and TAM in e-commerce environments: implications for systems design and management. IEEE Transactions on Engineering Management, v.57, n.3, p.380-393, 2010.

BHATTACHERJEE, A. Individual trust in online firms: scale development and initial test. Management Information System, v.19, n.1, p.211-242, 2002.

CARLSSON, C.; WALDEN, P.; BOWMAN, H.Adoption of 3Gp services in Finland. International Journal of Mobile Communication, v.4, n.4, p.369-385, 2006.

CHELlAPPA, R.; PAVLOU, P. Perceived information security, financial liability and consumer trust in electronic commerce transactions. Journal of Enterprise Information Management, v.15, n.5-6, 2002.

CRUZ, P.; GALLEGO P.; NETO L.; LAUKKANEN T. M-banking rollout in emerging markets: evidence from Brazil. International Journal of Bank Marketing, v.28, n.5, 2010.

CYBIS, W.; BETIOL, A.; FAUST, R.Ergonomia e usabilidade: conhecimentos, métodos e aplicações.São Paulo: Novatec, 2007.

DATAMONITOR m-banking: over-hyped gimmick or credible 21st century banking chanel? New York: Datamonitor, 2013.

DAVIS, F.; BAGOZZI, R.; WARSHAW, P.User acceptance of computer technology: a comparison of two theoretical models. Management Science, v.35, n.8, p.982-1002, 1989.

DAVIS, F. Perceived usefulness, perceived ease of use, and user acceptance of information technology. MIS Quarterly, v.13, n.3, p.319-339, 1989.

DIMITRIADIS, S.; KYREZIS, N. Linking trust to use intention for technology-enabled bank channels: the role of trusting intentions. Psychology \& Marketing, v.27, n.8, p.799-820, 2010.

FEBRABAN. Pesquisa Febraban de Tecnologia Bancária 2013. Available on: $<$ http://www.febraban. org.br/7Rof7SWg6qmyvwJcFwF7I0aSDf9jyV/sitefebraban/Pesquisa\%20FEBRABAN\%20de\%20 Tecnologia\%20Banc\%E1ria_2013.pdf>. Accessed on: 19 mar. 2015.

FEBRABAN. Pronunciamentos: Pesquisa FEBRABRAN de Tecnologia Bancária 2014. Available on: $<$ https://www.febraban.org.br/Noticias1.asp?id_texto=2626> Accessed on: 17 out. 2015

FISHBEIN, M.; AJZEN, I. Belief, attitude, intention and behavior: an introduction to theory and research. Reading, MA: Addison-Wesley Publishing, jun. 1975.

FORNELL, C.; LARCKER, D. Evaluating structural equation models with unobservable variables and measurement error. Journal of Marketing Research, v.18, n.1, p.39-50, 1981.

FRIEDMAN, P.; KAHN JR., D. Trust online. Communications of the ACM v.43, n, 12, p.34-40, 2000. 
BBR

15,2

189
GARTNER GROUP. Gartner Group dataquest insight: mobile payment, 2007-2012. Stamford, CT: Gartner Group, 2009.

GEFEN, D. E-commerce: the role of familiarity and trust. Omega, v.28, n.6, p.725-737, 2000.

GEFEN, D.; STRAUB, D. Consumer trust in B2C e-commerce and the importance of social presence: experiments in e-products and e-services. The International Journal of Management Science, v.32, n.6, p.407-424, 2004.

GOLDSMITH, R.; HOFACKER, C. Measuring consumer innovativeness. Journal of the Academy of Marketing Science, v.19, n.3, p.209-221, 1991.

GOUVEIA, F. Inovações tecnológicas priorizam mobilidade e segurança ao cliente. Inovação UNIEMP, Campinas, v. 3, n. 6, dez. 2007. Available on: <http://inovacao.scielo.br/scielo.php?script=sci_ arttext\&pid=S1808-23942007000600024\&lng=es\&nrm=iso>. Accessed on: 19 mar. 2015.

GRIFFIN, M.; BABIN, B.; ATTAWAY, J. Anticipation of injurious consumption outcomes and its impact on consumer attributions of blame. Journal of the Academy of Marketing Science, v.24, n.4, p.314-327, 1996.

GU, J.; LEE, S.; SUH, Y. Determinants of behavioral intention to m-banking. Expert System with Applications, v. 36, n.7, p. 11.605-11.616, 2009.

GULATI, R. Does familiarity breed trust? The implications of repeated ties for contractual choice in alliances. Academy of Management Journal, v.38, n.1, p.85-112, 1995.

HANAFIZADEH, P.; KHEDMATGOZAR, H. The meeting role of the dimensions of the perceived risk in the effect of customers awareness on the adoption of internet banking in Iran. Eletronic Commerce Research, v.12, n.2, p.151-175, 2012.

HANAFIZADETH, P.; BEHBOUDI, M.; KOSHKSARAY, A.; TABAR, M. Mobile-banking adoption by Iranian bank clients. Telematics and Informatics, v.31, n.1, p.62-78, 2014.

HU, L.; BENTLER, P. Cutoff criteria for fit indexes in covariance structure analysis: conventional criteria versus new alternatives. Structural Equation Modeling, v.6, p.1-55, 1999.

JARVEENPAA, S.; TRACTINSKY, N.; VITALE, M. Consumer trust in an internet store. Technol Manage, v.1, n.1, p.45-71, 2000.

KIM, D.; FERRIM, D.; RAO, H. Trust and satisfaction, two stepping stones for successful e-commerce relationships: a longitudinal exploration. Information Systems Research, v.20, n.2, p.237-257, 2008.

KIM, G.; SHIM,B.; LEE,H.Understanding dynamics between initial trust and usage intentions of m-banking. Information System Journal, v.19, n.3, p.283-311, 2009.

KULVIWAT, S.; BRUNER II, G.; KUMAR, A.; SUZANNE, A.; CLARK, T. Toward a unified theory of consumer acceptance technology. Psychology and Marketing, v.24, n.12, p.1059-1084, 2007.

LA POLLA, M.; MARTINELLI, F.; SGANDURRA, D. A survey on security for mobile devices. IEEE Communications Surveys \& Tutorials, v.15, n.1, p.446-471, 2013.

LEE, K.; CHUNG, N. Understanding factors affecting trust in and satisfaction with m-banking in Korea: a modified DeLone and McLean's model perspective. Interacting with Computers, v.21, n.5, p.85-392, 2009.

LEE, K.; KANG, I.; MCKNIGHT, D.Transfer from offline trust to key one perceptions: an empirical study. IEEE Transactions on Engineering Management, v.54, n.4, p.729-741, 2007.

LI, Y-M; YEH, Y-S. Increasing trust in mobile commerce through design aesthetics. Comput. Hum. Behav., v.26, n.4, p.673-684, 2010.

LIN, H. An empirical investigation of mobile banking adoption: The effect of innovation attributes and knowledge-based trust. International Journal of Information Management, v.31, n.3, 2011

LUARN, P., LIN, H. Toward an understanding of the behavioral intention to use m-banking. Computers in Human Behavior, v.21, n.6, p.873-891, 2005.

LUHMANN, N. Trust and power. Chichester: Wiley, 1979.

LUO, X.; LI, H.; ZHANG, J.; SHIM, J. Examining multi-dimensional trust and multi-faceted risk in initial acceptance of emerging technologies: An empirical study of mobile banking services. Decision Support Systems, v.49, n.2, p.222-234, 2010.

MALAQUIAS, R.; F.; HWANG, Y. An empirical study on trust in mobile banking: A developing country perspective. Computers in Human Behavior, v. 54, p. 453-461, 2016.

Marett, K.; Pearsona, A.; Pearsona, R.; Bergielb, E.Using mobile devices in a high risk context: the role of risk and trust in an exploratory study in Afghanistan. Technology in Society, v.41, p.54-64, 2015. 
MAYER, R;DAVIS, J.;SHOORMAN, F. An integrative model of Organizational trust. TheAcademy Of Management Review, v.20, n.3, p.709-734, 1995.

MAZZON, J.;HERNANDEZ, J. Mobile banking: proposition of an integrated adoption intention framework, International Journal of Bank Marketing, v.28 n.5, p.389-409, 2010

MCKNIGHT, D.; CHERVANY, N. What trust means in e-commerce customer relationships: an interdisciplinary conceptual typology. International Journal of Electronic Commerce, v.6, n.2, p. 35-59, 2002.

MCKNIGHT, D.; CHOUDHURY, V.; KACMAR, C. Developing and validating trust measures for e-commerce: an integrative typology. Information Systems Research, v.13, n.3, p.334-359, 2002.

MOHAMMADI, H. A study of mobile banking loyalty in Iran. Computers inHuman Behavior, 44, 35e47, 2015

MONTEZEMI, A. R.; SAREMI, H. Q. Factors affecting adoption of onlinebanking: a meta-analytic structural equation modeling study. Information andManagement, v. 52, p. 210-226, 2015

MORGAN, R.; HUNT, S. The commitment-trust theory of relationship marketing. Journal of Marketing, v.58, n.3, p.20-38, 1994.

MUKHERJEE A.; NATH, P. A model of trust in online relationship banking. International Journal of Bank Marketing, v.21, n.1, p.5-15, 2003.

OLIVER, R.; BEARDEN, W. Crossover effects in the theory of reasoned action: a moderating influence attempt. Journal of Consumer Research, v.12, n.3, p.324-340, 1985.

PARASURAMAN, A.; GREWAL, D.; KRISHNAN, R. Marketing research. 2. ed. South-Western College Pub, 2006.

PAVLOU, P.; FYGENSON, M. Understanding and predicting electronic commerce adoption: an extension of the theory of planned behavior. MIS Quarterly, v.30, n.1, p.115-143, 2006.

PEDERSEN, P. Adoption of mobile internet services: an exploratory study of mobile commerce early adopters. Journal of Organizational Computing and Eletronic Commerce, v.15, n.2, p.203-222, 2005.

PENNINGTON, R.; WILCOX, H.; GROVER, V. The role of system trust in business-to-consumer transactions. Journal of Management Information Systems, v.23, n.3, p.197-226, 2003.

RAMOS, A.; PIMENTA, I.; RODRIGUES, P. Diferenças de percepção de adotantes e não-adotantes quanto ao uso de serviços de m-banking e sua relação com as características individuais de inovatividade. Revista Pensamento Contemporâneo em Administração, v.4, n.3, p.34-43, 2010.

RIIVARI, J. M-banking: A powerful new marketing and CRM tool for financial services companies all over Europe. Journal of Financial Services Marketing, v.10,p.11-20, 2005.

ROGERS, E. Diffusion of innovation. 5. ed. New York: Free Press, 2003.

ROTTER J. Anew scale for the measurement of interpesonal trust. Journal of Personalityv.35, n.4, p.651$665,1967$.

SANTOS, D.; VEIGA, R.; MOURA, L. Teoria do comportamento planejado decomposto: determinantes de utilização do Serviço M-banking. Revista Organizações em Contexto, v.6, n.12, p.78-106, 2010.

SHAIKH, A. A.;KARJALUOTO, H. Mobile banking adoption: a literature review.Telematics and Informatics, v. 32, p.129-142, 2015.

SIAU, K.; SHEN, Z. Building customer trust in mobile commerce. Commun ACM, v.45, n.4, p.91-94, 2003.

SULAIMAN, A.; JAAFAR, N.; MOHEZAR, S. An overview of m-banking adoption among the urban community. International Journal of Mobile Communications, v.5, n.2, p.157-168, 2007.

SUORANTA, M.; MATTILA, M. M-banking and consumer behavior: new insights info the diffusion pattern. Journal of Financial Services Marketing, v.8, n.4, p.354-366, 2004.

SWAMINATHAN, V.; LEPKOWSKA-WHITE, E.; RAO, B. Browsers or buyers in cyberspace? An investigation of factors influencing electronic exchange. Journal of Computer-Mediated Communication, v.5, n.2, 1999.

TAYLOR, S.; TODD, P. A. Understanding information technology usage: a test of competing models. Information Systems Research, v.6, n.4, p. 144-176. 1995.

VANCE, A.; CHRISTOPHE, E.; STRAUB, D. Examining trust in information technology artifacts: the effects of system quality and culture. Journal Management Information System, v.24, n.4, p.73-100, 2008.

VENKATESH, V.; MORRIS, M.; DAVIS, G.; DAVIS, F. User Acceptance of Information Technology: Toward a Unified View. MIS Quarterly, v.27, n.3, p.425-478, 2003. 
VENKATESH, V.; THONG, J.; XU, X. Consumer acceptance and use of information technology: extending the unified theory of acceptance and use of technology. MIS Quarterly v.36, n.1 p.157-178, 2012

WANG, S. W., NGAMSIRIUDOM, W.; HSIEH, C.-H. Trust disposition, trust antecedents,trust, and behavioral intention. The Service Industries Journal, v. 35, n.10,p.555-572, 2015.

WU, C; HUANG, Y.; HSU, C. Benevolence trust: a key determinant of user continuance use of online social networks. Indo Syst E-Bus Manage, Springer-Verlag Berling Heindelberg, v.12, p.189-211, 2013. YU, CHIAN-SON. Antecedents and Consequences of Trust in Using Mobile Banking. MIS REVIEW, v. 20, n. 2, p. 27-56, 2015.

ZHOU, T. An empirical examination of initial trust in m-banking. Internet Research, v.21, n.5, p.527-540, 2011a.

ZHOU, T. Examining $\mathrm{m}$-banking user adoption from the perspectives of trust and flow experience. Springer Science+Business Media, LLC 2011b.

ZHOU T. Understanding user's initial trust in m-banking: an elaboration likelihood perspective. Computer in Human Behavior, v.28, n.4, p.1518-1525, 2013. 